\title{
Evaluation of the effectiveness of the use of instruments to attract savings in Kazakhstan (for example, "BCC Invest” JSC)
}

\author{
Gulmira Kassenova ${ }^{1, *}$, Gulnar Nurgalieva ${ }^{1}$, Ryszard Pukala $^{2}$, Aizhan Agatayeva ${ }^{1}$, Nazgul \\ Syrlybayeva ${ }^{1}$ \\ ${ }^{1}$ Al-Farabi Kazakh National University, al-Farabi Ave. 71, 050040 Almaty, Kazakhstan \\ ${ }^{2}$ The Bronisław Markiewicz State Higher School of Technology and Economics in Jarosław, \\ Czarnieckiego 16, 37-500 Jarosław, Poland
}

\begin{abstract}
The growth of population's savings, their socio-economic structure, and the efficiency of the use of these resources in a modern market economy - all this is of fundamental importance for the formation of the most important proportions of expanded reproduction. Moreover, savings significantly determining the direction of the investment process, the scale and structure of demand and supply, and affects the cyclical nature economic development, including the emergence of crises. With the development of the financial market, securities began to play a crucial role in the mechanism of formation and use of savings. The stock market is an important element of the mechanism for turning people's savings into investments. The stock market functioning affects the preservation and enhancement of savings, the growth of the welfare of the population and the strengthening of socioeconomic stability in society. In modern economic theory, the category of savings occupies one of the leading places. The economic interests of all classes of society, social strata intersect in solving a variety of socioeconomic issues related to the functioning of the category of savings. In the system of economic relations, consumption, savings and investments are both the result and condition of the reproduction process.
\end{abstract}

\section{Introduction}

The stock market is a significant, but not the only area of the economy where savings take the form of investments. Savings of different sectors of society and corporations and even the state in the securities market act as capital. This is the initial advance value for which its owners acquire securities, subsequently earning income in the form of a dividend or in the form of a difference in their market value. Moreover, the circulation of capital invested in securities hides the real circulation and turnover of industrial capital. In this aspect, attracting the savings of the population to the stock market is a specific process both in form and in the mechanisms of movement to convert savings into investments. Despite the fact that the modern stock market of Kazakhstan is in constant development, and market institutions

\footnotetext{
${ }^{*}$ Corresponding author: guka_71@mail.ru
} 
constantly develop and offer private investors new financial products and services, most of the savings of the population are unorganized.

Under the conditions of modern economic instability, the specificity of the formation and use of savings is manifested in the fact that a considerable amount of free cash resources is concentrated in the hands of potential private investors. The population begins to more actively direct these monetary resources to consumption or leaves it on a "hard day", as a rule, in cash at home or in safe deposit boxes of banks. At the same time, the real sector of the economy is in dire need of this money. Therefore, it is necessary in this way to build the process of raising funds so that it optimally meets the interests and needs of both the population and the national economy.

\section{Results and discussions}

Evaluation of the effectiveness of the use of instruments to attract savings of the population should be understood as a comparison of the use of instruments in terms of efficiency for all parties to the circulation of funds. It can immediately be noted that in this case, the determination of effectiveness is a rather complicated action.

Why? Because in this complex action - there are common interests and there are multidirectional interests (conflict of interests) between the existing or participating parties. The first side is a population that has savings, does not have special knowledge of investing, but wants to earn income on existing savings (capital). The second side is specialists who have special knowledge of investing, and who want to use this knowledge, i.e. also want income.

The third party is the real sector of the economy, or simply the market (entrepreneurship), which has the means of production, which also wants to earn income, but which needs some financial resources to carry out activities or for its development. The picture of attracting monetary resources to the real economy is as follows (Figure 1).

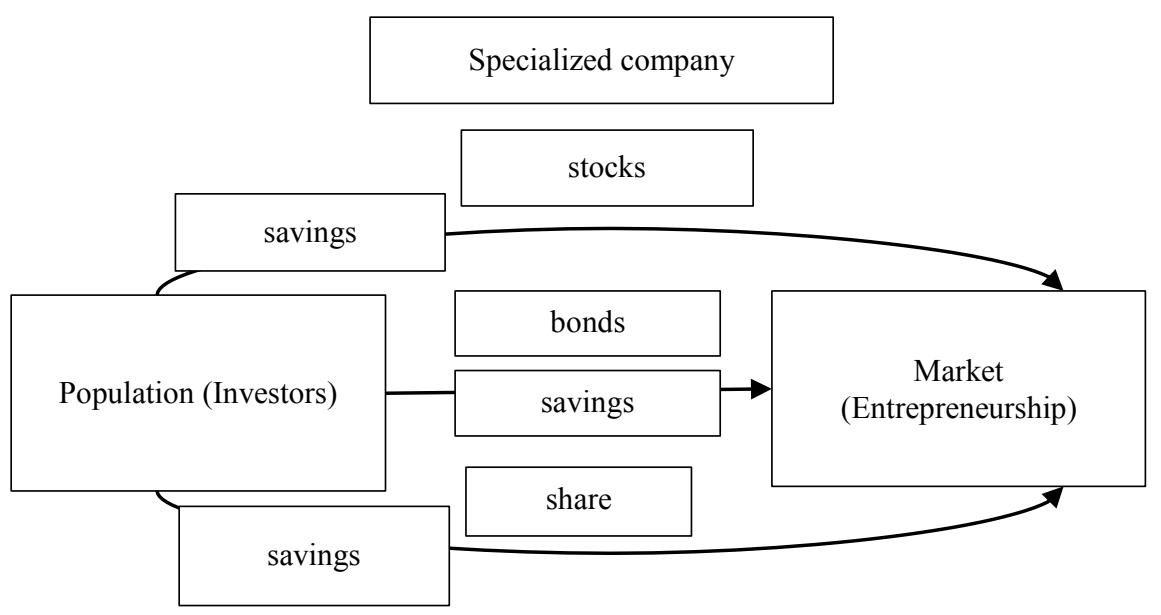

Note: compiled by authors

Fig. 1. Tools for attracting savings (investing capital) in the economy.

Figure 1 shows that the population wishing to receive income in the securities market should enter into a relationship with the Specialized company that will be an assistant in the implementation of investment activities of the population. At the same time, the Specialized 
Company - an assistant in the stock market - wants to receive a fee for its services. The stock market is a complex organized market for the distribution of available financial resources of investors on the market, expressed in the form of sale of securities; this market is regulated and controlled by the state. Regulation and control of the state over the order and transparency in the stock market is necessary, since it, like any other market, has risks of unclean behavior of participants, especially for the organizer of tenders (Kazakhstan Stock Exchange "KASE)" and special companies that know the specifics of the stock market.

Figure 1 shows that the Market (Entrepreneurship) in the stock market receives the necessary financial resources in exchange for securities. Securities for the Population (Investors) are confirmation, firstly, of the conclusion of the transaction, and secondly, they are an obligation on the part of the market to pay a certain percentage of the use of the attracted savings of the population.

The forms of securities are different (stocks, bonds, share), which means are differences in the terms of the transaction of these different forms of securities, but the general thing is that payment for the use of financial resources must be mandatory, otherwise it is not securities. The Payment is the percentage determined by the transaction for the use of the attracted savings of the population (Figure 2).

From Figure 2, we can, conclude that the difference in the percentage of the use of the savings of the population, depending on the form of securities, will represent the difference in the effectiveness of the use of the instrument and, accordingly, an assessment can be made, but this is true only on the one hand - from the outside income from capital. And there is also the legal side, which determines the legal status of the holder of securities, the content of the rights and obligations of the parties for each form of security, there are risks and responsibility of the parties. Therefore, this figure shows only the goal of attracting people's savings to the market - generating income for all parties involved.

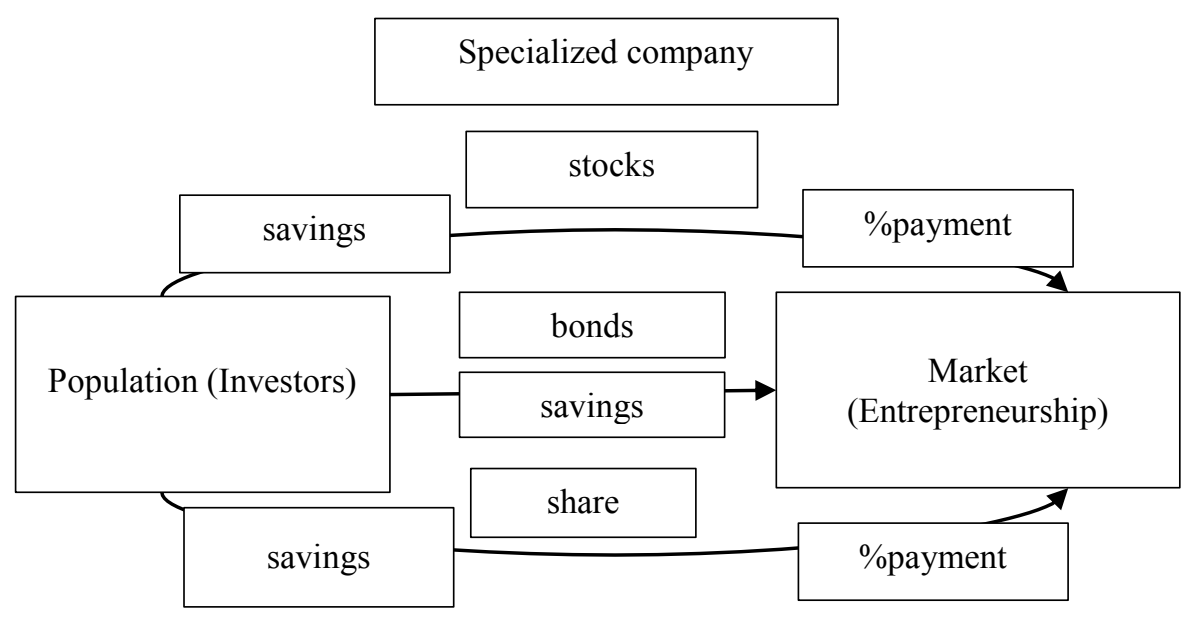

Note: compiled by authors

Fig. 2. Payment for the use of savings attracted from the population.

Features or differences of securities: stocks, bonds and share. On the stock market of the Republic of Kazakhstan they are circulated in non-documentary form, and operations to change the ownership of them are carried out using the stock exchange software and the central depository in the form of electronic records. In addition to capital income, a share also gives a voting right at a general meeting of shareholders, i.e. to a certain extent, it can 
be used to manage the company [1]. The basic conditions for the circulation of the bond is the term of circulation, interest on the bond, and the return of the nominal value of the bond at the end of the circulation period [2].

In relation to a share, this is a complex relationship for the organization of a joint investor, without the formation of a legal entity, and a management company for managing the monetary resources of shareholders combined into one investment fund. The construction of Table 1 gives the following picture.

Table 1. An approximate pattern of differences in the characteristics of stocks bonds and share

\begin{tabular}{|l|c|c|c|c|}
\hline Name of securities & $\begin{array}{c}\text { Company's management by } \\
\text { Issuer }\end{array}$ & $\begin{array}{c}\text { Returnability } \\
\text { investment }\end{array}$ & Income & The risks \\
\hline Stock & Yes & $\begin{array}{c}\text { Depends on } \\
\text { demand }\end{array}$ & Yes & Yes \\
\hline Bond & No & Yes & Yes & Yes \\
\hline Share & Not a legal entity & Yes & Yes & Yes \\
\hline Note: compiled by authors
\end{tabular}

Thus, the tools presented are different in attracting the savings of the population to the stock market, and each of them has its own advantages and disadvantages. Therefore, we can note the main circumstance, which is an obstacle to the mass attraction of savings of the population. The main circumstance - it is the complexity of relationships that frighten the population with their incomprehensible concepts and legal constructions and, ultimately, the uncertainty of achieving the ultimate goal of generating income, therefore this stock market for the population is complex and very risky. With regard to assessing the effectiveness of the application of instruments to attract people's savings, it is first necessary to determine what is meant by efficiency.

Evaluation should be understood as a comparison between the effectiveness of the use of tools, and efficiency can be understood as the optimal (optimal means the best) way of attracting monetary savings of the population in the economy. In addition, efficiency should be understood as the difference between the costs of acquiring a useful thing by the parties (population, specialist and market) and the benefits received from the acquired thing. If the difference is positive, then the parties won, if the difference is negative, then the parties lose. Therefore, all parties should benefit from attracting the savings of the population. In the case of evaluating the effectiveness of instruments to attract the savings of the population, it is necessary to consider the effectiveness of the use of stocks, bonds and share. However, since the difference in income is different, and this depends on the percentage invested in capital and risk, this is a determining point that must necessarily be reflected in the real economy. The reflection of the market's choice of the most effective instrument in attracting savings of the population can be seen in the statistics, which are maintained by the regulator - the National Bank of the Republic of Kazakhstan (Table 2).

Table 2. Issuance of stocks, bonds and share (units, quarterly) by issuers of the Republic of Kazakhstan

\begin{tabular}{|l|c|c|c|c|c|c|c|}
\hline & $\begin{array}{c}2 \text { quarter } \\
2017\end{array}$ & $\begin{array}{c}3 \text { quarter } \\
2017\end{array}$ & $\begin{array}{c}4 \text { quarter } \\
2017\end{array}$ & $\begin{array}{c}1 \text { quarter } \\
2018\end{array}$ & $\begin{array}{c}2 \text { quarter } \\
2018\end{array}$ & $\begin{array}{c}3 \text { quarter } \\
2018\end{array}$ & $\begin{array}{c}4 \text { quarter } \\
2018\end{array}$ \\
\hline $\begin{array}{l}\text { Number of current } \\
\text { stock issues }\end{array}$ & 1254 & 1241 & 1217 & 1205 & 1202 & 1196 & 1192 \\
\hline $\begin{array}{l}\text { Number of current } \\
\text { bond issues }\end{array}$ & 388 & 394 & 402 & 393 & 398 & 392 & 411 \\
\hline
\end{tabular}




\begin{tabular}{|l|c|c|c|c|c|c|c|}
\hline $\begin{array}{l}\text { Number of current } \\
\text { share issues * }\end{array}$ & 29 & 23 & 28 & 28 & 26 & 24 & 32 \\
\hline Total: & 1671 & 1658 & 1647 & 1626 & 1626 & 1610 & 1635 \\
\hline & * managed by investment portfolio managers \\
Note: compiled by authors based on source data [2]
\end{tabular}

On the stock market of the Republic of Kazakhstan, state and non-government securities are used as instruments to attract people's savings. The state as well as entrepreneurship needs borrowing, and therefore can be a participant in relations in the stock market. In the fourth quarter of 2018 , the total number of active issues of corporate securities increased by $1.6 \%$ and as of January 1, 2019 amounted to 1,635 units [3]. Figure 3 shows the general movement in the securities market.

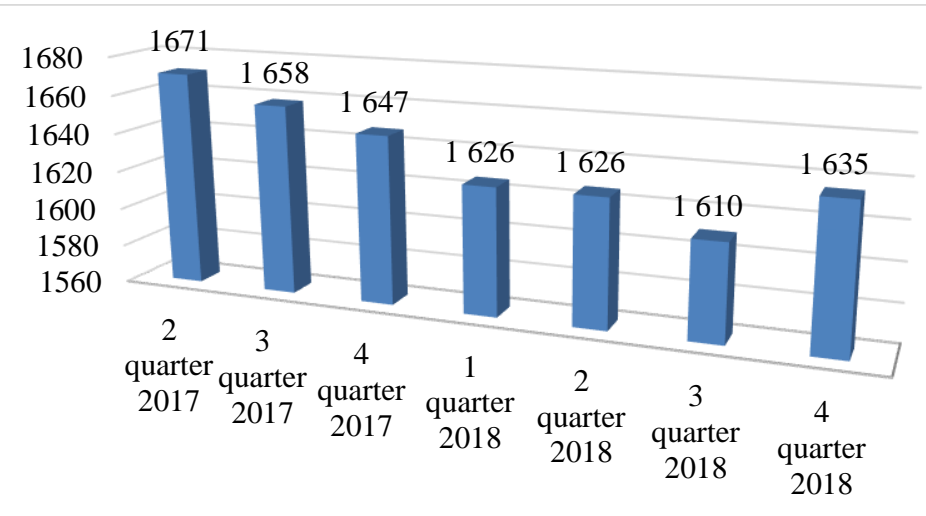

Note: compiled by authors based on source data [2]

Fig. 3. The total number of current issues of corporate securities.

According to Figure 3, it can be observed that with a decrease in the number of existing issues of corporate securities, there is a decrease in the activity of the population on the securities market. In the period from October 1, 2018 to December 31, 2018, 44 issues of corporate securities were registered. At the same time, securities were mainly issued by organizations that operate in the field of finance [4, 5]. This statement by analysts of the National Bank may lead to the conclusion that financial institutions need savings of the population to a greater extent than enterprises from the real economy.

The number of registered issues of securities by categories for 2017-2018 presented in Table 3.

Table 3. The number of registered issues of securities by categories for 2017-2018 (units, quarterly).

\begin{tabular}{|c|c|c|c|c|c|c|c|}
\hline & 2 quarter & 3 quarter & 4 quarter & 1 quarte & 2 quarter & 3 quarter & 4 quarter \\
\hline & 2017 & 2017 & 2017 & 2018 & 2018 & 2018 & 2018 \\
\hline $\begin{array}{l}\text { Number of registered stock } \\
\text { issues }\end{array}$ & 6 & 6 & 2 & 3 & 10 & 8 & 8 \\
\hline $\begin{array}{l}\text { Number of registered bond } \\
\text { issues }\end{array}$ & 10 & 11 & 16 & 7 & 11 & 7 & 28 \\
\hline $\begin{array}{l}\text { Number of registered share } \\
\text { issues }\end{array}$ & 2 & 1 & 6 & 0 & 0 & 1 & 8 \\
\hline Total: & 18 & 18 & 24 & 10 & 21 & 16 & 44 \\
\hline
\end{tabular}


The data in Table 3 can be presented for clarity in the form of Figure 4. According to Figure 4, one can single out bonds as the most effective form of attracting savings, especially in the fourth quarter of 2018, shares are in second place by efficiency, and shares are in third place. The data of Figure 4 allow us to conclude that the bond market seems to be the most profitable or effective (with lower risks for the population).

Now directly about the company and the offer.

The investment company BCC Invest, a subsidiary of Bank CenterCredit JSC, the creation of which (by re-registering KIB Asset Management JSC) in 1998 was driven by market needs and the growing potential of investment banking. As of January 2020, it provides a main number of the following services: Brokerage and dealer activities; Customer asset management (Investment products for population: "CenterCredit - Currency" Interval Investment Fund, "Smart Balance" Interval Investment Fund); Corporate Financing; Direct investments $[6,7,8]$.

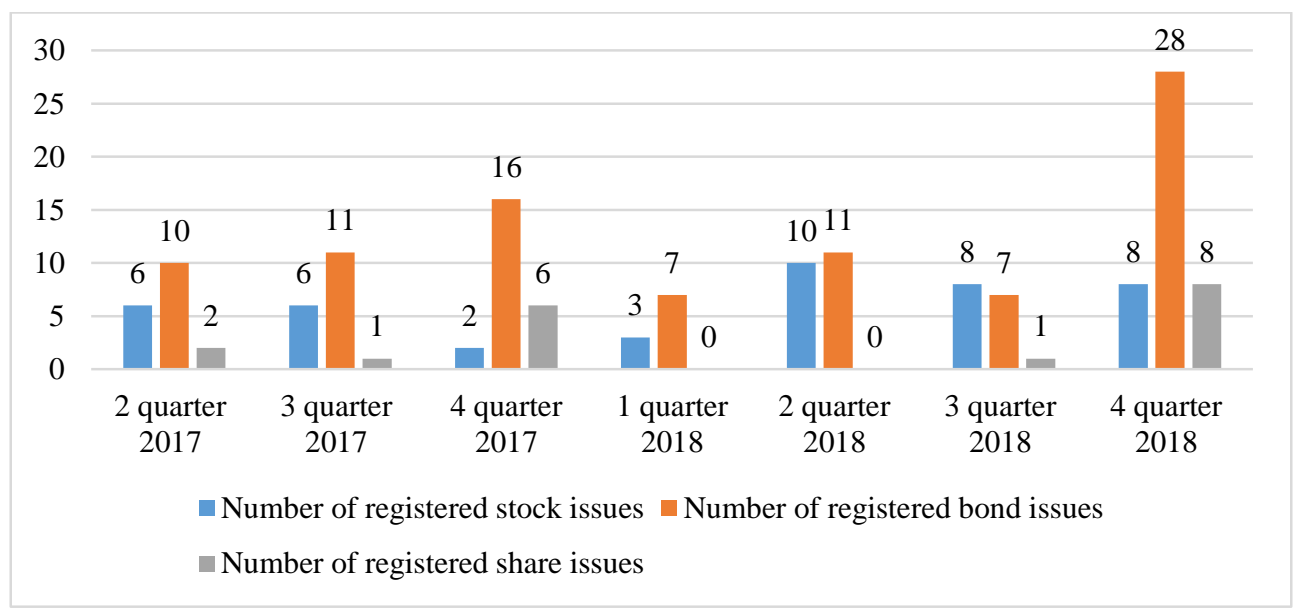

Note: compiled by authors based on source data [2]

Fig. 4. Market activity in the selection of forms of instruments for attracting savings of the population.

The "CenterCredit - Currency" Interval Investment Fund was established with the aim of providing investors with the opportunity to save and increase their financial assets in hard currencies. The investment strategy of the Fund was developed in the direction of extracting interest income in the form of coupon payments and dividends, also in order to receive income from value growth in order to maintain and increase fixed capital. Each quarter, the fund pays dividends to shareholders for $5 \%$ per annum (which is $1.25 \%$ per quarter). The minimum contribution amount is 10 thousand dollars, and the annual fund management fee is $1 \%$ of the amount. Those who wish to leave the Interval Investment Fund can do this by selling their shares, but this can only be done once a quarter, which means 4 times a year. The shortest period during which you can withdraw the deposit is 12 months. If necessary, it is possible to withdraw money up to 12 months. Then the depositor must pay a discount to restore the interests of other investors. Payment is: from 0 months to 12 months $-1 \%$ of invested assets; over 12 months - 0\% [9, 10].

The "Smart balance" Interval Investment Fund of BCC Invest JSC is managed according to a balanced strategy. Balanced strategy most preferred for those investors who need a balanced portfolio, backed by active management. To achieve a balance of profitability and risk, assets are distributed between shares that are recognized as potentially highly profitable and fixed income instruments (for example, bonds and deposits). At the same time, investors 
are informed that the state cannot act as a guarantor of income from investments invested in investment funds.

According to Figure 5, one can note the growth of holders of shares, which is a reflection of the growing market interest in Interval Investment Fund, as the most attractive from the point of view of profitability, and from the point of view of risk, which, of course, has reason.

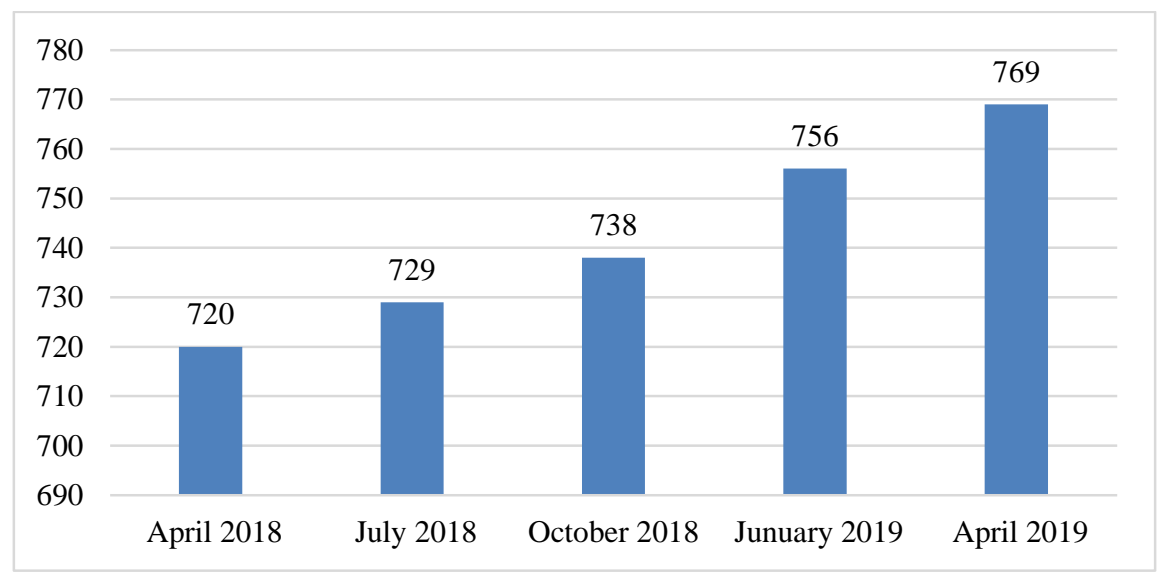

Note: compiled by authors based on source data [12]

Fig. 5. Change in the number of shareholders of investment funds (for 4 quarters).

Thus, the market of mutual investment funds is interesting for investors, therefore, one can observe a gradual increase in investor activity in this area. For the purpose of this study, a population survey was conducted to identify interest in investing savings in securities [11, 12]. Questions were drawn up that determined the general interest of the population in investing in securities, and preferences in instruments. The survey involved 79 individuals: 57 men, 22 women aged 25 to 60 years. Answers to respondents' questions are presented in Table 4.

Table 4. Indicator of public interest in investing in securities, and preferences in instruments.

\begin{tabular}{|l|l|l|l|l|}
\hline & Questions & Yes & No & $\begin{array}{c}\text { Difficult to } \\
\text { answer }\end{array}$ \\
\hline 1 & Have you thought about investing in securities? & 62 & 8 & 9 \\
\hline 2 & Have you heard of the IPO? & 25 & 47 & 7 \\
\hline 3 & Did you participate in the IPO? & 12 & 57 & 0 \\
\hline 4 & $\begin{array}{l}\text { Do you have sufficient financial literacy to make decisions on } \\
\text { investing in securities? }\end{array}$ & 6 & 60 & 13 \\
\hline 5 & Do you trust Kazakhstan's securities market? & 18 & 47 & 14 \\
\hline 6 & Do you plan to participate in the IPO? & 14 & 65 & 0 \\
\hline \multicolumn{2}{|l|}{ Note: compiled by authors } & \multicolumn{2}{|l|}{} \\
\hline
\end{tabular}

According to the responses received, particular ones are those that are "fetters" in the development of the securities market, namely: this is the lack of financial literacy among the population and low confidence in the securities market.

The result showed that $76 \%$ or more $3 / 4$ of the respondents surveyed do not have financial literacy, and $13 \%$ found it difficult to answer. In total, $89 \%$ of respondents, or almost $9 / 10$, 
are unlikely to risk their money savings and invest in the securities market. Of particular interest is the issue of confidence in the securities market in Kazakhstan (Figure 7).

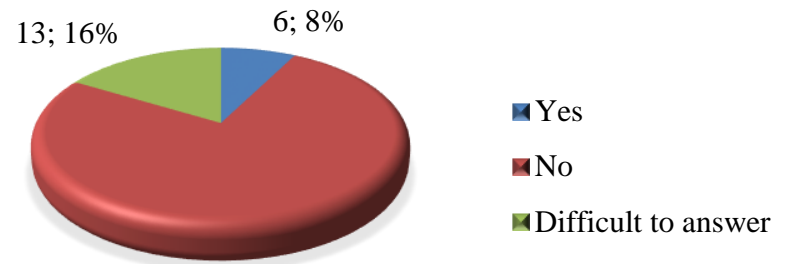

$60 ; 76 \%$

Note: compiled by authors

Fig. 6. Analysis of the answers to the fourth question of the questionnaire on the adequacy of financial literacy for investing in securities.

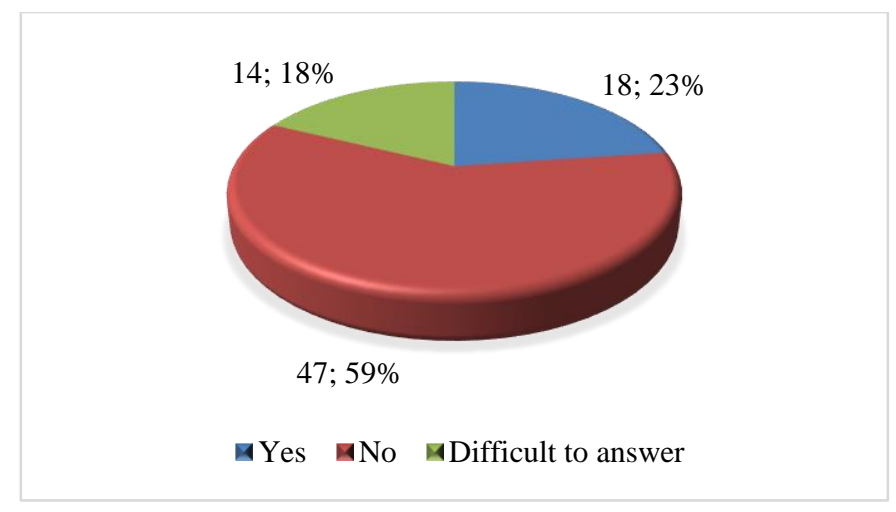

Note: compiled by authors

Fig. 7. Analysis of the answers to the fifth question of the questionnaire on the adequacy of financial literacy for investing in securities.

The result obtained in Figure 7 showed that $59 \%$ or less than $2 / 3$ of the respondent's surveyed do not trust the Kazakhstan's securities market, and $18 \%$ found it difficult to answer. In total, $77 \%$ of the respondents or more $3 / 4$ do not trust the Kazakhstan's securities market and, accordingly, do not expect these people to trust their savings to the securities market.

\section{Conclusion}

Thus, an assessment of the effectiveness of the use of instruments in attracting savings of the population showed that the bond market is considered the most effective from the point of view of the market [13]. A population survey showed that the main obstacle in attracting people's savings to participate in the development of the securities market is the lack of financial literacy and a certain mistrust of the population in the stock market of Kazakhstan $[14,15]$. 
From the practical side it seems very important for the Kazakhstan economy. The stock market is an important element of the mechanism for turning people's savings into investments, especially since the interest of the population of Kazakhstan in this type of attraction of their savings has begun to grow noticeably, which, of course, reflects the general mood and development trends of the domestic economy and the presence of socio-economic stability in society.

The considered example of an investment company ("BCC Invest" JSC) showed that the interest of the population could be activated through the active involvement of specialized stock market players with affordable terms of payment for services.

\section{References}

1. The securities market of the Republic of Kazakhstan. [Electronic resource]: https://nationalbank.kz

2. Alekseev, M. Yu., Securities Market, 352 (Finance and Statistics, Moscow, 2014)

3. Kravchenko, Yu. Ya., Securities Market: Lecture Course, 24 (VIRA-R, Kiev, 2012)

4. Alekhine, B. I., Securities Market, 461 (Peter, Moscow, 2017)

5. Kolesnikova, I., Torkanovsky, B.C., Securities. Textbook, 69 (Finance and Statistics, Moscow, 2014)

6. Petrov, M. I., Legal regulation of the securities market, 240 (Peter, Moscow, 2017)

7. Meirzhanov, S. S., Bulletin of KazEU, 7-10 (2014)

8. The Supreme Council of the Republic of Kazakhstan, The Civil Code of the Republic of Kazakhstan (General Part) (1994)

9. Website of JSC "BCC Invest" https://www.bcc-invest.kz

10. Website of KSE http://old.kase.kz/

11. The National Bank of Kazakhstan, The securities market of the Republic of Kazakhstan https://nationalbank.kz

12. A. D. Umbitaliev, K. K. Nurasheva, D. A. Kulanova, Zh. Sh. Kadyrova, International journal of applied and fundamental research, 9(1), 178-180 (2014)

13. Zhanbolatova, A., Ziyadin, S., Zhumanov, K., \& Jumabekova, A., Banks \& bank systems, 13(1), 98-114 (2018). DOI: 10.21511/bbs.13(1).2018.10

14. A.V. Sibirskaya, Finance and Credit, 23(4), 201-216 (2017)

15. A. K. Kubasova, Zh. K. Tastemirova, B. Z. Mukhtarova, M. A. Mekin, European journal of economics and management sciences, 58-60 (2017) 